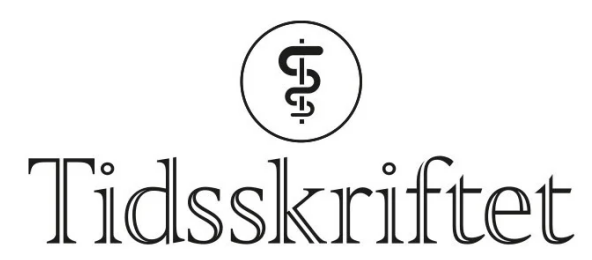

DEN NORSKE LEGEFORENING

\title{
Bjørn Ødegaard
}

\author{
MINNEORD
}

KIRSTEN LUNDGREEN

SØREN BJERRE

$\varnothing Y S T E I N$ HøVIK

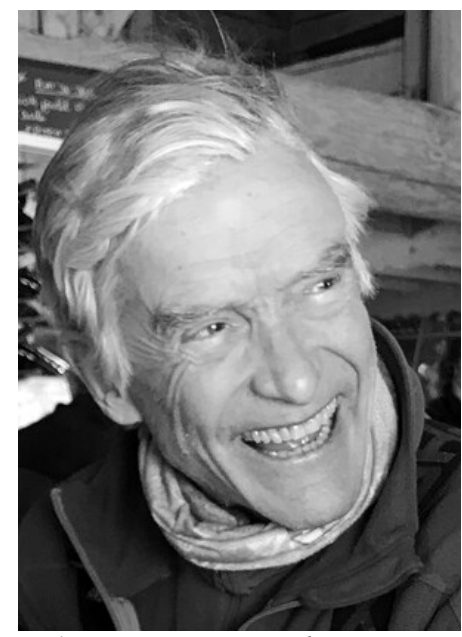

Vi har mistet en god venn og en enestående kollega.

Det er fortsatt vanskelig å begripe at vår kjære venn og kollega ortoped Bjørn Ødegaard ikke lenger skal jobbe sammen med oss på Ortopedisk avdeling ved Lovisenberg Diakonale sykehus. I en alder av 72 spreke år døde han brått 8. mars 2021. Bjørn har gjennom sine 30 år ved sykehuset vært sentral $i$ utviklingen av avdelingen, og da spesielt i etablering av skulderprotesekirurgien.

Hele hans virke har vært preget av ungdommelig glede og nysgjerrighet etter ny kunnskap for å gi pasientene den beste behandlingen. Han brydde seg oppriktig om pasientene sine og fulgte dem samvittighetsfullt opp. Vi er uendelig takknemlige for alt han har lært oss, både det teknisk faglige, men også gleden over arbeidet og livet. Ved krevende operasjoner var det alltid godt å ha med Bjørn, som elegant og trygt kunne guide oss gjennom enhver 
utfordring. Han var en av disse personene som gjennom sin gode og trygge væremåte fikk de rundt seg til å vokse og skinne. Dette nøt vi godt av ikke bare på jobb, men også ved sosiale sammenkomster.

I alpinbakken suste Bjørn lekent av gårde med imponerende teknisk kjøring og barnlig, nesten umettelig glede over fart og utfordringer - tidvis til fortvilelse for yngre kollegaer som ikke klarte å henge med. Det faktum at han hadde både nasjonale og internasjonale medaljer i alpine grener nevnte han aldri. Han var i sannhet en beskjeden mann, men et stort menneske.

Vi sørger og savner vår gode, positive Bjørn med det lune smilet og det glade glimtet i øyet.

Våre varmeste tanker går til hans kjære Jannicke, deres barn og barnebarn.

Vi lyser fred over Bjørn Ødegaards minne.

På vegne av kollegaene og medarbeiderne ved Kirurgisk klinikk, Lovisenberg Diakonale Sykehus

Publisert:3. mai 2021. Tidsskr Nor Legeforen. DOI: 10.4045/tidsskr.21.0207

(C) Tidsskrift for Den norske legeforening 2023. Lastet ned fra tidsskriftet.no 26. april 2023. 